\title{
MICROWAVE IRRADIATED SYNTHESIS AND H-BONDING NETWORK OF BIOLOGICALLY ACTIVE NANOCRYSTALLINE Cd(II) COMPLEX WITH HETEROATOM ('N' \&'O') DONOR LIGANDS
}

\author{
K. Rajasekar ${ }^{1, *}$, T. Gomadurai ${ }^{1}$, S. Balasubramaniyan ${ }^{1}$, R. Selvarani ${ }^{1}$, \\ C. Veeravel ${ }^{1}$ and R. Geetha ${ }^{1}$ \\ 1PG \& Research Department of Chemistry, Government Arts College, \\ Ariyalur-621713, Tamil Nadu, India \\ *E-mail: yokkesh111@gmail.com
}

\begin{abstract}
The post-transition diamagnetic complex of $\mathrm{Cd}(\mathrm{II})$ with benzimidazole (' $\mathrm{N}$ ' Donor) and nitrite ion ( nitrito-O, 'O' Donor) heteroatom ligands were synthesized and characterized by elemental analysis, estimation of metal ion, conductance $\left(10^{-3} \mathrm{M}\right.$ complex solution), UV-Visible, IR, Far-IR, NMR spectra, SEM and X-ray diffraction (single crystal method). The complex was crystallized in orthorhombic P2 $122_{1}$ space group having a $=8.8701(3) \AA, b=$ $11.5026(4) \AA$ and $c=22.5665(8) \AA$. The interfacial angle of crystal are $\alpha=\beta=\gamma=90^{\circ}$, volume and density of the crystallized complex were $2302.44(14) \AA^{3}$ and $1.612 \mathrm{mg} / \mathrm{m}^{3}$ respectively. Cd(II) ion is surrounded by two oxygen atom of nitrite ion and three nitrogen atom of benzimidazole by distorted pentagonal bipyramidal structure. SEM images of the crystal also discussed the morphology. Biological activities against bacterial and fungal strains viz., Klebsiella pnemoniae and salmonella typhi (gram-negative bacteria), Bacillus subtilis (gram-negative bacteria) and pathogenic yeast $C$. albicance were carried out by Agar well diffusion method. On comparing benzimidazole the complex crystal shows potent activities against tested microorganisms.
\end{abstract}

Keywords: Cd(II) Complex, Benzimidazole, Microwave Irradiation, Nanocrystal, Pentagonal Bipyramidal

(C) RASĀYAN. All rights reserved

\section{INTRODUCTION}

Nitrogen and oxygen donor heteroatomic ligand was used to the efficient formation of coordination complexes with transition and post-transition metal ions due to the presence of lone pair of electrons on the donor atoms and vast bio-potential activities. Benzimidazole is one of the heterocyclic, monodentate, neutral and biologically active ligand which can coordinate through nitrogen atom of them ${ }^{1-2}$. In pharmaceutical industries, benzimidazole acts as a pharmacophore used to synthesized biologically active compounds..$^{3-4}$ its derivatives with transition metal ions play a vital role in bio-molecules viz., vitamin B12 and metalloproteins. Benzimidazole is one of the imperative antimicrobial, anticancer, anti-inflammatory, antivirus, anti-ulcer, and anticonvulsant agent in biofield. ${ }^{5-7}$ The nitrogen donor benzimidazole and its derivatives have two ring systems with different functional group leads to the change in physicochemical, geometry, pharmacokinetics property and bio-potential activities. ${ }^{8-10}$ In the present exploration paying attention to the microwave irradiated synthesis, crystal structure and bio-potential activities of posttransition $\mathrm{Cd}(\mathrm{II})$ complex with benzimidazole ('N-donor) and nitrite ion ('O' donor).

\section{Materials and Methods}

\section{EXPERIMENTAL}

All the chemicals such as benzimidazole (Alfa Aesar), sodium nitrite, $\mathrm{CH}_{3} \mathrm{OH}, \mathrm{C}_{2} \mathrm{H}_{5} \mathrm{OH}$, DMSO, DMF and Cadmium nitrite were purchased from scientific suppliers and used as such without further purification. They are all AnalaR grade.

Rasayan J. Chem., 12(2), 866-873(2019)

http://dx.doi.org/10.31788/RJC.2019.1225108

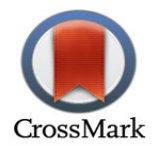


Elements present in the synthesized crystal were detected from Thermo Finnegan make, Flash EA1112 series $\mathrm{CHNS}(\mathrm{O})$ analyzer instrument. The conductivity of the $10^{-3} \mathrm{M}$ complex in $\mathrm{CH}_{3} \mathrm{CN}$ at $30^{\circ} \mathrm{C}$ was carried out using Systronic Conductivity Bridge. The UV-visible spectrum of the complex by diffused reflectance spectra (DRS) method was measured by using Varian carry-5000 model UV-Visible spectrophotometer. IR spectrum of benzimidazole and Cd(II) complex were carried out at $4000-400 \mathrm{~cm}^{-1}$ wave number using Schimadzu FT-IR8400s spectroscopy with $\mathrm{KBr}$ pellet technique. The ${ }^{1} \mathrm{H}-\mathrm{NMR}$ and ${ }^{13} \mathrm{C}-\mathrm{NMR}$ spectra of the diamagnetic Cd(II) complex and ligand INH were recorded in the DMSO-d6 solvent on a $500 \mathrm{MHz}$ FT NMR spectroscopy using Tetramethylsilane as an internal standard. Bruker D8 Venture SC-XRD system is used for structure determination of single crystal. It is a combination of two $\mathrm{X}$-ray sources (Mo \& $\mathrm{Cu}$ ) with a highly accurate goniometer. The photon $100 \mathrm{CMOS}$ detector is optimized for both $\mathrm{Mo}(\mathrm{K} \alpha)$ and $\mathrm{Cu}(\mathrm{K} \alpha)$ radiation. The wavelength is fully automated. The bio-potential activities (antibacterial and antifungal) Cd(II) complex were done by in-vitro Agar well diffusion method using the standard Amikacin and Ketoconazole and also comparing with free benzimidazole.

\section{Preparation of Complex}

$\mathrm{Cd}(\mathrm{II})$ crystal was synthesized by mixing benzimidazole $1.52 \mathrm{~g}(6.48 \mathrm{mmol})$ in $5 \mathrm{ml}$ methanol with $2 \mathrm{~g}(3.24$ $\mathrm{mmol})$ of $\mathrm{Cd}\left(\mathrm{NO}_{3}\right)_{2} .4 \mathrm{H}_{2} \mathrm{O}$ in $5 \mathrm{ml}$ methanol and sodium nitrite $0.90 \mathrm{~g}(6.52 \mathrm{mmol})$ in ethanol solution was mixed then the mixture was irradiated on a microwave oven for 10 seconds. The precipitated colorless complex was filtered, washed with 1:1 ethanol:water and dried. The crystal is stable at room temperature and the yield is $80 \%$.

\section{UV Spectra}

\section{RESULTS AND DISCUSSION}

The UV-spectra of the complex shows the charge transfer spectra at $267 \mathrm{~nm}$ (MLCT) and $338 \mathrm{~nm}$ (LMCT) due to the completely filled d orbital of $\mathrm{Cd}(\mathrm{II})$ metal ion in the complex. The charge transfer spectra (C-T band) only possible in the complex. ${ }^{11}$

\section{IR Spectrum}

The IR spectrum of benzimidazole shows the $v(\mathrm{C}=\mathrm{H})$ at $3112 \mathrm{~cm}^{-1}, v(\mathrm{~N}=\mathrm{H})$ at $3063 \mathrm{~cm}^{-1} v(\mathrm{C}-\mathrm{C})$ at 1620 $\mathrm{cm}^{-1}$ and $v(\mathrm{C}-\mathrm{C})$ in ring at $1458 \mathrm{~cm}^{-1}$ stretching frequencies in the free state but after complexation these frequencies are shifted to $3174 \mathrm{~cm}^{-1} 3057 \mathrm{~cm}^{-1} 3112 \mathrm{~cm}^{-1} 1622 \mathrm{~cm}^{-1} 1462 \mathrm{~cm}^{-1}$, the $v(\mathrm{~N}-\mathrm{H})$ in plane and out of plane stretching frequencies at $617 \mathrm{~cm}^{-1}$ and $626 \mathrm{~cm}^{-1}$ upon coordination through the nitrogen atom of benzimidazole these stretching frequencies are shifted to $582 \mathrm{~cm}^{-1}, 578 \mathrm{~cm}^{-1}$ respectively confirming the planarity changes during complexation and further it is concluded the effective formation of complexes. ${ }^{12}$ Nitrite ion shows the $v_{\mathrm{a}}(\mathrm{ONO})$ asymmetric and symmetric stretching $v_{\mathrm{sy}}(\mathrm{ONO})$ frequencies at $1270 \mathrm{~cm}^{-1}$ and1362 $\mathrm{cm}^{-1}$ respectively. The separation of asymmetric and symmetric frequency calculates by $\Delta^{\mathrm{a}}$ factor. The $\Delta^{\mathrm{a}}$ factor value is at $112 \mathrm{~cm}^{-1}$ which depend upon the degree of symmetry of the nitrito-O group in the complex. ${ }^{13}$ Higher the value of $\Delta^{\mathrm{a}}$ indicating the $\mathrm{N}=\mathrm{O}$ and $\mathrm{N}-\mathrm{O}$ bonds are nonequivalent which increases the degree of symmetry.

\section{FAR-IR Spectra}

Far-IR spectra of the synthesized crystal confirming by the metal linked atom capability. Obviously, the far IR spectra of the complex show the stretching frequencies at $429 \mathrm{~cm}^{-1}$ is ascribed to the $v(\mathrm{M}-\mathrm{N})$ linkage of benzimidazole nitrogen donor site. ${ }^{14}$ The nitrite ion (ambidentate ligand) can coordinate through the oxygen donor site is confirming by $v(\mathrm{M}-\mathrm{O})$ at $344 \mathrm{~cm}^{-1}$

\section{NMR- Spectra}

The ${ }^{1} \mathrm{H}-\mathrm{NMR}$ spectrum of benzimidazole shows the chemical shift values at $12.50 \mathrm{ppm}$ for $\mathrm{N}-\mathrm{H}$ proton (singlet), $8.25 \mathrm{ppm}$ for $\mathrm{N}=\mathrm{C}-\mathrm{H}$ (singlet) and 7.17-7.20 ppm for aromatic proton (multiplet). In diamagnetic $\mathrm{Cd}$ (II) complex the N-H chemical shift value shifted to downfield at $12.63 \mathrm{ppm}$ whereas $\mathrm{N}=\mathrm{C}-\mathrm{H}$ is not shifted $(8.25 \mathrm{ppm})$. The aromatic protons are slightly shifted to downfield at 7.21-7.63 ppm. ${ }^{15-16}$ The ${ }^{13} \mathrm{C}-\mathrm{NMR}$ spectra of the ligand give four different chemical shift values corresponding to the carbon atom present in the benzimidazole (ligand). The $\mathrm{N}=\mathrm{C}$ at $141.90 \mathrm{ppm}, \mathrm{C} 2$ at $138.09 \mathrm{ppm}, \mathrm{C} 3$ at 
$121.71 \mathrm{ppm}$ and $\mathrm{C} 4$ at $115.36 \mathrm{ppm}$. In complex, these are shifted to downfield at $143.43 \mathrm{ppm}, 137.01 \mathrm{ppm}$, $122.64 \mathrm{ppm}$, and $115.52 \mathrm{ppm}$ respectively indicating the effective formation of coordination complex site through the nitrogen atom of benzimidazole. ${ }^{17}$

\section{Crystal Structure Depiction of the Complex ${ }^{18-19}$}

In the crystal structure of $\mathrm{Cd}(\mathrm{II})$ ion is seven coordinated by three donor nitrogen atom of benzimidazole ( 3 units) ligand and four oxygen atoms of each anionic nitrite ions. $\mathrm{Cd}(\mathrm{II})$ ions show distorted pentagonal bipyramidal structure with $\mathrm{N} 1, \mathrm{~N} 4, \mathrm{~N} 6$ from benzimidazole and $\mathrm{O} 1, \mathrm{O} 2, \mathrm{O} 3, \mathrm{O} 4$ from nitrite ion. All the atoms are coplanar in nature and the complex is crystallized by orthorhombic crystal system with $\mathrm{P} 2{ }_{1} 2_{1} 2_{1}$ space group. The unit cell parameters $\mathrm{a} \neq \mathrm{b} \neq \mathrm{c}(\mathrm{a}=8.8701, \mathrm{~b}=11.5026, \mathrm{c}=22.5665)$ but the angle is equal to $90^{\circ}\left(\alpha=\beta=\gamma=90^{\circ}\right)$. The selected bond angles of metal coordinate bonds are $\mathrm{N}_{6}-\mathrm{Cd}-\mathrm{N}_{1}$ at $169^{\circ}, \mathrm{N}_{6}$ $\mathrm{Cd}-\mathrm{N}_{4}$ at $92.99^{\circ}, \mathrm{N}_{1}-\mathrm{Cd}-\mathrm{N}_{4}$ at $96.85^{\circ}, \mathrm{O}_{2}-\mathrm{Cd}-\mathrm{O}_{1}$ at $49^{\circ}$ and $\mathrm{O}_{4}-\mathrm{Cd}-\mathrm{O}_{2}$ at $79.45^{\circ}$ are also confirming the coordination site and structure of the crystal.

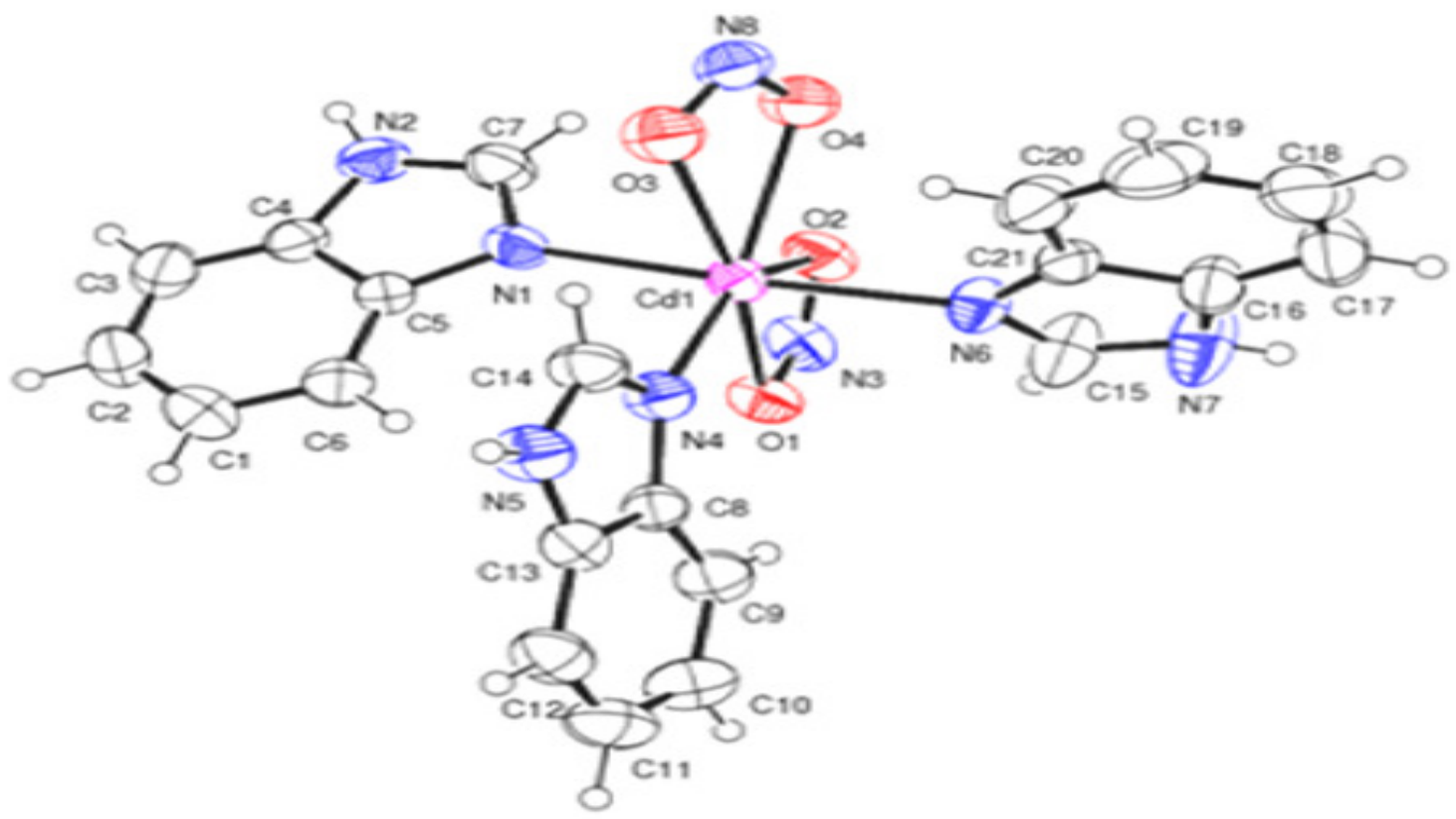

Fig.-1: Crystal Structure of Cd(II) Complex

Table-1: Crystal Data and Structure Refinement for Cd(II) Complex

\begin{tabular}{lll}
\hline Identification code & $\mathrm{G} 11$ & \\
\hline Empirical formula & $\mathrm{C}_{21} \mathrm{H}_{18} \mathrm{Cd} \mathrm{N}_{8} \mathrm{O}_{4}$ & \\
\hline Formula weight & 558.83 & \\
\hline Temperature & $296(2) \mathrm{K}$ & \\
\hline Wavelength & $0.71073 \AA$ & \\
\hline Crystal system & Orthorhombic & \\
\hline Space group & $\mathrm{P} 2{ }_{1} 2_{1}$ & \\
\hline Unit cell dimensions & $\mathrm{a}=8.8701(3) \AA$ & $\beta=90^{\circ}$. \\
\hline & $\mathrm{b}=11.5026(4) \AA$ & \\
\hline & $\mathrm{c}=22.5665(8) \AA$ & \\
\hline Volume & $2302.44(14) \AA$ & \\
\hline$Z$ & 4 & \\
\hline Density (calculated) & $1.612 \mathrm{Mg} / \mathrm{m}^{3}$ & \\
\hline Absorption coefficient & $0.994 \mathrm{~mm}^{-1}$ & \\
\hline
\end{tabular}


RASĀYAN J. Chem.

Vol. 12 | No. 2 |866 - 873| April - June | 2019

\begin{tabular}{ll}
\hline $\mathrm{F}(000)$ & 1120 \\
\hline Crystal size & $0.200 \times 0.150 \times 0.100 \mathrm{~mm}^{3}$ \\
\hline Theta range for data collection & 2.467 to $24.997^{\circ}$. \\
\hline Index ranges & $-9<=\mathrm{h}<=10,-13<=\mathrm{k}<=12,-26<=1<=26$ \\
\hline Reflections collected & 37912 \\
\hline Independent reflections & $4057[\mathrm{R}(\mathrm{int})=0.0538]$ \\
\hline Completeness to theta $=24.997^{\circ}$ & $99.9 \%$ \\
\hline Absorption correction & Semi-empirical from equivalents \\
\hline Max. and min. transmission & 0.7452 and 0.6728 \\
\hline Refinement method & Full-matrix least-squares on $\mathrm{F}^{2}$ \\
\hline Data / restraints / parameters & $4057 / 3 / 319$ \\
\hline Goodness-of-fit on $\mathrm{F}^{2}$ & 1.104 \\
\hline Final R indices [I $>2$ sigma(I)] & $\mathrm{R} 1=0.0255, \mathrm{wR} 2=0.0406$ \\
\hline R indices (all data) & $\mathrm{R} 1=0.0448, \mathrm{wR} 2=0.0473$ \\
\hline Absolute structure parameter & $-0.028(11)$ \\
\hline Extinction coefficient & $\mathrm{n} / \mathrm{a}$ \\
\hline Largest diff. peak and hole & 0.502 and $-0.473 \mathrm{e} . \AA^{-3}$ \\
\hline
\end{tabular}

\section{SEM Image of the Crystal}

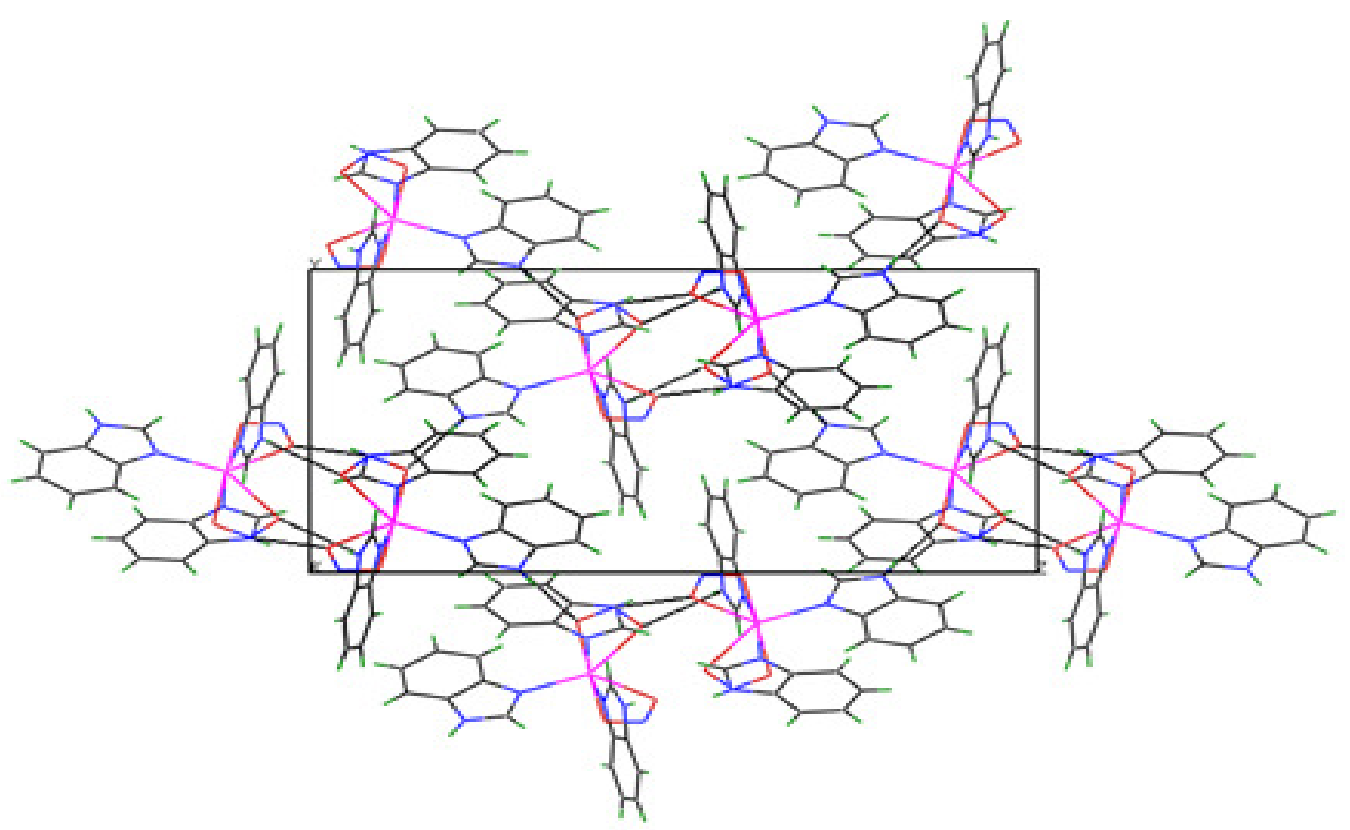

Fig.-2: 3-D Network of H-Bonded Cd(II) Complex

The morphological and structural properties of Cd(II) complex were evaluated by using a SEM image (scanning electron microscope). The SEM images magnifying under different size $(2 \mu \mathrm{m}, 3 \mu \mathrm{m}, 10 \mu \mathrm{m} \&$ $20 \mu \mathrm{m})$. The SEM image of the crystal confirmed by the heterogeneity and Nanocrystal nature of the complex. ${ }^{20}$

\section{Bio-Potential Activities of the Crystal}

Bio-potential activities of benzimidazole and its $\mathrm{Cd}$ (II) complex were carried out by Agar well diffusion method using gram-negative bacteria Klebsiella pneumonia and pathogenic yeast $C$. albicance. The results indicating that the compound shows enhanced antibacterial and antifungal activities on comparing the standard as well as a ligand.

The enhanced activity of the complex explain on basis of ligand structure, donor site of ligand (N/O) and overtone's chelation theory concept which is explain on the basis of lipophilicity of the complex which is 
RASĀYAN J. Chem.

Vol. 12 | No. 2 |866 - 873| April - June | 2019

an significant factor that controls the antibacterial/antifungal activity because of the lipid membrane that surrounds the cell favors the passage of only lipid soluble matter. Chelation is further increases the delocalization of $\pi$-electrons over the ring in the ligand which enhance the lipophilicity of the metal complex. ${ }^{21-22}$

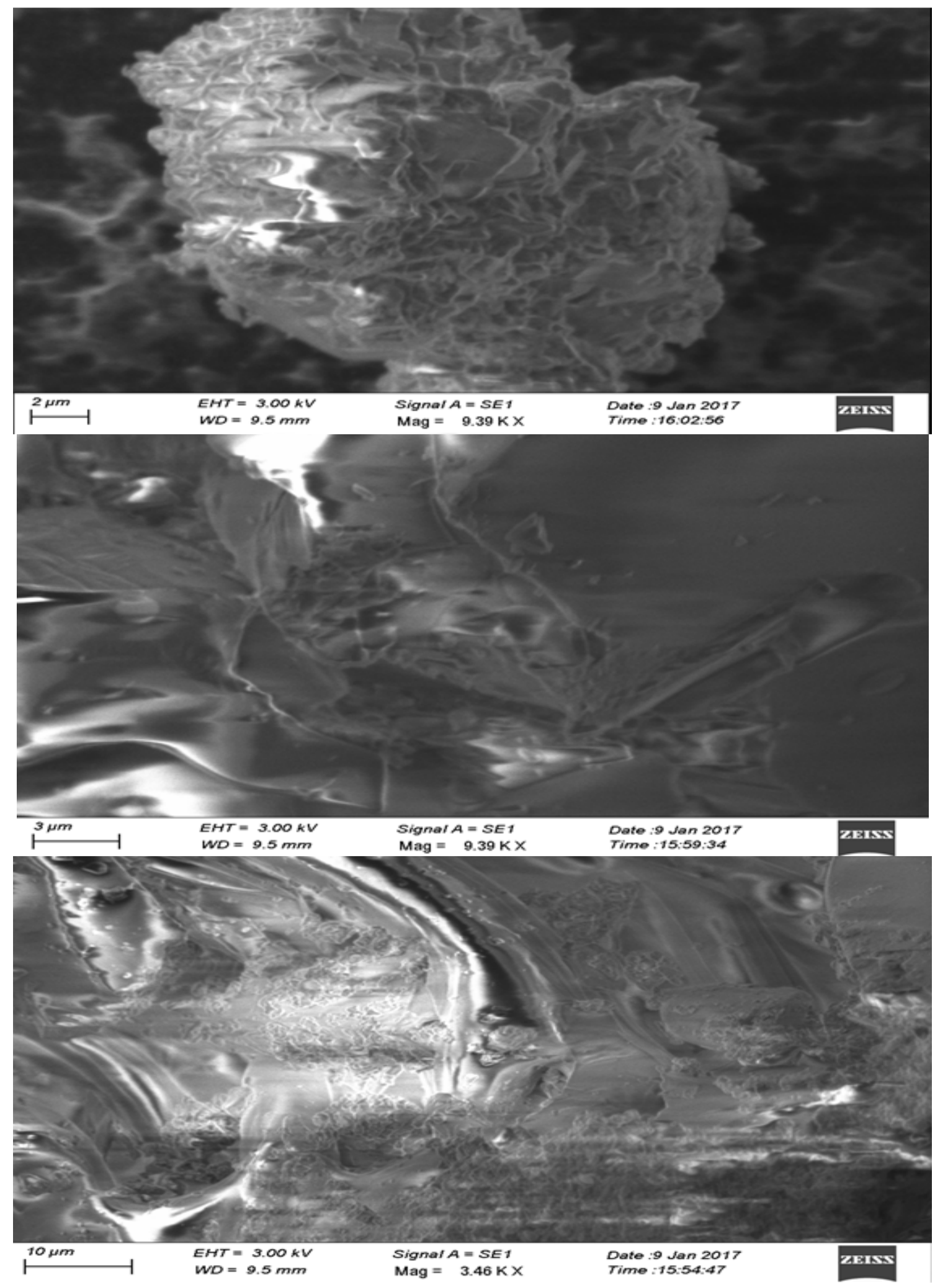


RASĀYAN J. Chem.

Vol. 12 | No. 2 |866 - 873| April - June | 2019

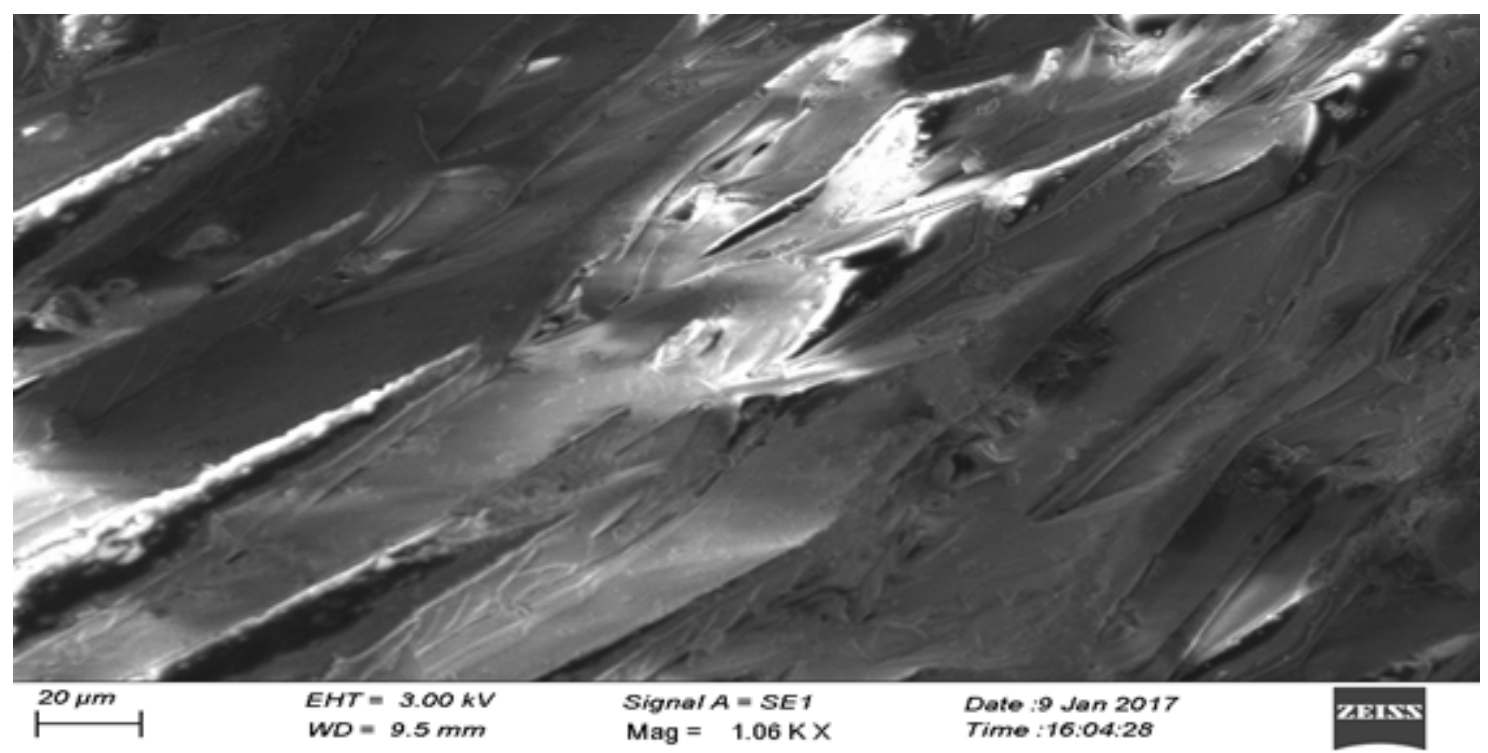

Fig.-3 SEM Images of Cd(II) Complex

Table-2: Selected Bond lengths $[\AA]$ and angles $\left[{ }^{\circ}\right]$ for $\mathrm{Cd}(\mathrm{II})$ Complex

$\begin{array}{cc}\mathrm{C}(1)-\mathrm{C}(6) & 1.378(7) \\ \mathrm{C}(1)-\mathrm{C}(2) & 1.385(8) \\ \mathrm{C}(1)-\mathrm{H}(1) & 0.9300 \\ \mathrm{C}(2)-\mathrm{C}(3) & 1.364(7) \\ \mathrm{C}(2)-\mathrm{H}(2) & 0.9300 \\ \mathrm{C}(3)-\mathrm{C}(4) & 1.370(7) \\ \mathrm{C}(3)-\mathrm{H}(3) & 0.9300 \\ \mathrm{C}(4)-\mathrm{N}(2) & 1.389(6) \\ \mathrm{C}(4)-\mathrm{C}(5) & 1.391(7) \\ \mathrm{C}(5)-\mathrm{C}(6) & 1.388(6) \\ \mathrm{C}(5)-\mathrm{N}(1) & 1.390(6) \\ \mathrm{C}(6)-\mathrm{H}(6) & 0.9300 \\ \mathrm{C}(7)-\mathrm{N}(1) & 1.323(6) \\ \mathrm{C}(7)-\mathrm{N}(2) & 1.336(7) \\ \mathrm{C}(7)-\mathrm{H}(7) & 0.9300 \\ \mathrm{C}(8)-\mathrm{C}(9) & 1.378(6) \\ \mathrm{O}(3)-\mathrm{N}(8)-\mathrm{O}(4) & 112.6(4) \\ \mathrm{N}(3)-\mathrm{O}(1)-\mathrm{Cd}(1) & 102.5(3) \\ \mathrm{N}(3)-\mathrm{O}(2)-\mathrm{Cd}(1) & 94.5(3) \\ \mathrm{N}(8)-\mathrm{O}(3)-\mathrm{Cd}(1) & 95.3(3) \\ \mathrm{N}(8)-\mathrm{O}(4)-\mathrm{Cd}(1) & 101.9(3) \\ \mathrm{N}(4)-\mathrm{Cd}(1)-\mathrm{N}(6) & 92.99(15) \\ \mathrm{N}(4)-\mathrm{Cd}(1)-\mathrm{N}(1) & 96.85(15) \\ \mathrm{N}(6)-\mathrm{Cd}(1)-\mathrm{N}(1) & 169.06(15) \\ \mathrm{N}(4)-\mathrm{Cd}(1)-\mathrm{O}(4) & 133.68(14) \\ \mathrm{N}(6)-\mathrm{Cd}(1)-\mathrm{O}(4) & 83.96(14) \\ \mathrm{N}(1)-\mathrm{Cd}(1)-\mathrm{O}(4) & 92.63(14) \\ \mathrm{N}(4)-\mathrm{Cd}(1)-\mathrm{O}(1) & 96.77(13) \\ \mathrm{N}(6)-\mathrm{Cd}(1)-\mathrm{O}(1) & 87.95(13) \\ \mathrm{N}(1)-\mathrm{Cd}(1)-\mathrm{O}(1) & 86.16(13) \\ \mathrm{O}(4)-\mathrm{Cd}(1)-\mathrm{O}(1) & 129.12(12) \\ \mathrm{N}(4)-\mathrm{Cd}(1)-\mathrm{O}(3) & 86.08(14) \\ \mathrm{N}(6)-\mathrm{Cd}(1)-\mathrm{O}(3) & 102.21(14) \\ \mathrm{N}(1)-\mathrm{Cd}(1)-\mathrm{O}(3) & 83.28(13) \\ \mathrm{O}(4)-\mathrm{Cd}(1)-\mathrm{O}(3) & 50.15(11) \\ \mathrm{O}(1)-\mathrm{Cd}(1)-\mathrm{O}(3) & 169.32(13) \\ & \\ & \end{array}$




$\begin{array}{lr}\mathrm{N}(4)-\mathrm{Cd}(1)-\mathrm{O}(2) & 146.62(13) \\ \mathrm{N}(6)-\mathrm{Cd}(1)-\mathrm{O}(2) & 85.90(12) \\ \mathrm{N}(1)-\mathrm{Cd}(1)-\mathrm{O}(2) & 83.25(13) \\ \mathrm{O}(4)-\mathrm{Cd}(1)-\mathrm{O}(2) & 79.45(12) \\ \mathrm{O}(1)-\mathrm{Cd}(1)-\mathrm{O}(2) & 49.86(11) \\ \mathrm{O}(3)-\mathrm{Cd}(1)-\mathrm{O}(2) & 126.80(12)\end{array}$

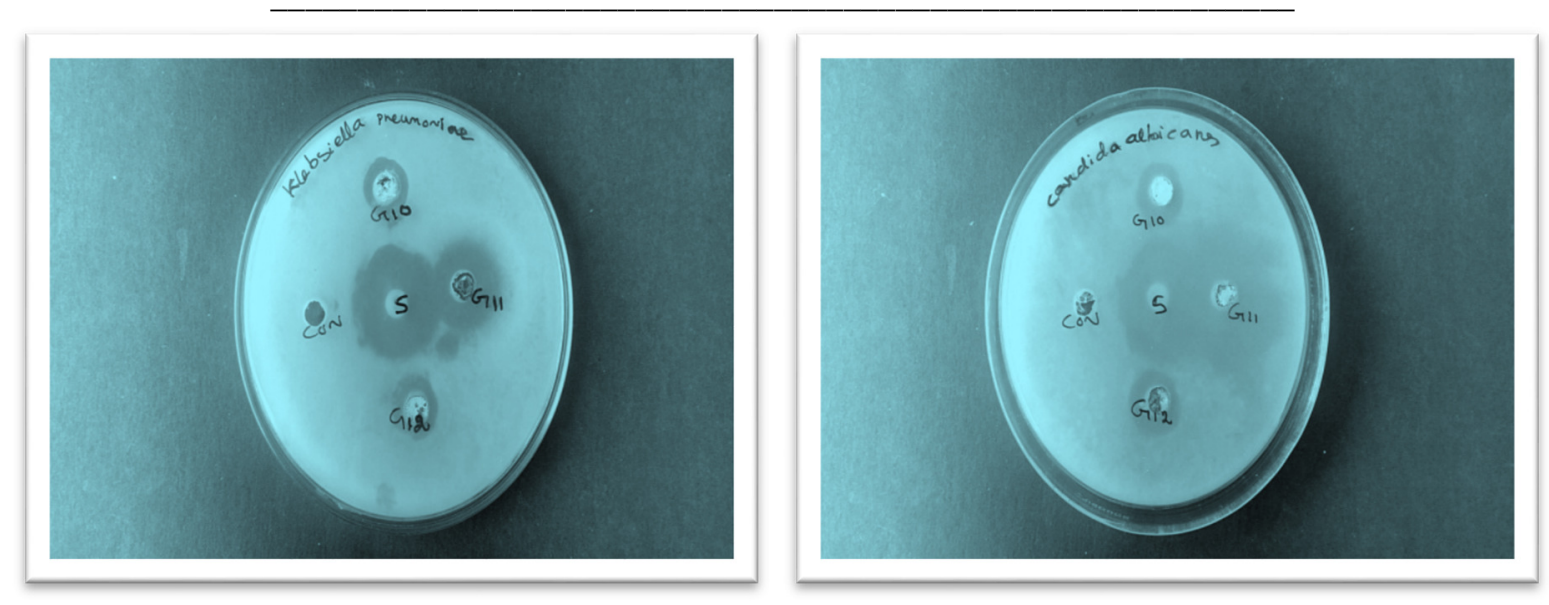

\section{Supplementary Materials}

Fig.-4 Zone of Inhibition of Cd(II) Complex

Crystallographic data for the $\mathrm{Cd}(\mathrm{II})$ complex have been deposited to the Cambridge Crystallographic data Centre. 12, Union Road, Cambridge CB2 1E2, UK.

CCDC number for the complex is 1523352. Copies of this information of the compounds obtained from Cambridge Crystallographic Data Centre with free of cost by the following the link. http://www.ccdc.cam.ac.uk/deposit@ccdc.cam.ac.uk

\section{CONCLUSION}

$\mathrm{Cd}(\mathrm{II})$ complex synthesized using benzimidazole and nitrite ion as ligands with microwave heating. The complex crystallized with distorted pentagonal bipyramidal structure having $\mathrm{a}=8.8701, \mathrm{~b}=11.5026$, $c=22.5665$ and angle $\alpha=\beta=\gamma=90^{\circ}$. The crystal is non-electrolyte, coordinate through the nitrogen atom of benzimidazole and oxygen atom of nitrite ion. It is biologically active against the tested microorganisms. The complex is Nanocrystalline in nature.

\section{ACKNOWLEDGMENT}

The authors are very much grateful to the Principal and Head Department of Chemistry, gives the opportunity to make the facilities available in the Department. We must thank the Head and Staff members of SAIF, Chennai, Mumbai, STIC, Cochin, Harman Research Institute and CIF S.t Joseph's College, Trichy providing XRD, spectral, analytical and biological facilities.

\section{REFERENCES}

1. Suman Malik, Archana Singh and Nayaz Ahmed, Advances in Applied Science Research, 6(8), 199(2015).

2. M. Sunita, B. Anupama, B. Ushaiah, C. GyanaKumari, Arabian Journal of Chemistry, 10, S3367(2017), DOI: 10.1016/j.arabjc.2014.01.017.

3. Robin Kumar, KuldeepMahiya and PavanMathur ,Indian Journal of Chemistry, 50A, 775(2011), DOI: $10.1007 / 978-90-481-2642-2 \_369$.

4. Fabiola Téllez, HoracioLópez-Sandoval, Silvia E. Castillo-Blum, and Noráh Barba-Behrens, ARKIVOC (v), 245-275 (2008). 
RASĀYAN J. Chem.

Vol. 12 | No. 2 |866 - 873| April - June | 2019

5. Adnan Ashraf Waseeq, Ahmad Siddiqui, Jamshed Akbar, Ghulam Mustafa, Harald Krautscheid, Nazif Ullah, Bushra Mirza, Falak Sher, Muhammad Hanif, and Christian G. Hartinger, Inorganica Chimica Acta, 443(24), 179(2016), DOI:10.1016/j.ica.2015.12.031.

6. Elif Apohan, Ulku Yilmaz, Ozgur Yilmaz, Ayfer Serindag, Hasan Küçükbay, Ozfer Yesilada, Yusuf Baran, Journal of Organometallic Chemistry, 828(1), 52(2017), DOI:10.1016/j.jorganchem.2016.11.020.

7. Shadia A. Galal, Khaled H. Hegab, Ahmed S. Kassab, Mireya L. Rodriguez, Sean M. Kerwin, AbdelMo'men A. El-Khamry, Hoda I. El Diwani, European Journal of Medicinal Chemistry, 44(4), 1500(2009), DOI: 10.1016/j.ejmech.2008.07.013

8. Ganesan Kumaravel and Natarajan Raman, Materials Science and Engineering: C, 70(1) , 184(2017), DOI: 10.1016/j.msec.2016.08.069

9. C. Rajnák, B. Schäfer, I. Šalitroš, O. Fuhr, M. Ruben and R. Boča, Polyhedron, 135, 189(2017), DOI: $10.1016 /$ j.poly.2017.06.035

10. Shadia A. Galal, Khaled H. Hegab, Ahmed M. Hashem, Nabil S. Youssef, European Journal of Medicinal Chemistry, 45(12), 5685(2010), DOI:10.1016/j.ejmech.2010.09.023

11. Pradip Kr. Dutta, Snigdha and Panda Sanjio S. Zade, Inorganica Chimica Acta, 411,83 (2014), DOI:.10.1016/j.ica.2013.11.030

12. Kirill I. Petko, Yurii, P. Kokhanovskii, Oleksii V. Gutov, Eduard, B. Rusanov, Yurii L. Yagupolskii and Lev M. Yagupolski, Journal of Organometallic Chemistry, 739, 11(2013), DOI: 10.1016/j.jorganchem.2013.04.019

13. Naresh H. Tarte, Seong Ihl Woo, Liqiang Cui, Young-Dae Gong, Young Ho Hwang, Journal of Organometallic Chemistry, 693(4), 729(2008), DOI: 10.1016/j.jorganchem.2007.12.001

14. Feriel Aouatef Sahkiyamine Messaadia, Hocine Merazig, Aissa Chibani, Abdelmalek Bouraiou and Soiane Bouacida, J. Chem. Sci., 129(1), 21(2017), DOI: 10.1007/s12039-016-1210-1

15. Shayma A.Shaker, Hamid Khaledi, Shiau-Chuen Cheah, and Hapipah Mohd Ali, Arabian Journal of Chemistry, 9(2), S1943(2016), DOI: 10.1016/j.arabjc.2012.06.013

16. Shanxi Wang, Yuxin Cui, Renxiang Tan, Qinhui Luo, Jianqui Shi and Qiangjin Wu, Polyhedron, 13(11), 1661(1994), DOI:.10.1016/S0277-5387(00)80094-7

17. P. Jeyanthi and P. Pazhanisamy, Rasayan J. Chem., 3(2), 214(2010).

18. Aydin Tavman and Cigdem Sayil, J. Serb. Chem. Soc., 80(1), 45(2015), DOI: DOI: $10.2298 / \mathrm{JSC} 140415081 \mathrm{~T}$

19. Gehad G. Mohamed, Nasser A. Ibrahim, Hanaa A. E. Attia, Spectrochimica Acta Part A: Molecular and Biomolecular Spectroscopy,72(3), 610(2009), DOI: 10.1016/j.saa.2008.10.051

20. Jiyong $\mathrm{Hu}$, YanGuo, Jin'an Zhao, Junshuai Zhang, Bioorganic \& Medicinal Chemistry, 25(20), 5733(2017), DOI: .10.1016/j.bmc.2017.08.053

21. Sutha Shobana, Jeyaprakash Dharmaraja, Shanmugaperumal Selvaraj, Spectrochimica Acta Part A: Molecular and Biomolecular Spectroscopy, 107, 117 (2013), DOI:10.1016/j.saa.2013.01.024.

22. Prem Shankar Mishra, P. Shanmugasundaram, Rakhi Chaudhary and M. Vijey Aanandhi, Rasayan J. Chem., 3(1), 51(2010).

[RJC-5108/2018] 